\title{
The Framework of Development Online Learning based on Interactive Multimedia Learning in STIKOM Bali
}

\author{
Muhammad Rusli \\ STMIK STIKOM Bali \\ Raya Puputan 86, Renon, Denpasar-Indonesia
}

\begin{abstract}
In this millennium era, interactive learning via multimedia has already encountered, whether on the internet, mobile phone, or desktop. The development of learning increasing rapidly since there is the development of multimedia technology software and hardware. With the development of technology, certainly very possible harmonious multimedia faster learning and innovative, yet still meet the elements of the effectiveness of a multimedia learning, usability and usefulness. In order to meet these elements, in the construction/development, course developers need to apply one of several models or methods of development of multimedia learning, among others: ADDIE (analysis, design, develop, implementation, and evaluation), DDE (Design, Develop, and Evaluation), or Delphi. This paper is part of the online learning application development research of a subject in STMIK STIKOM Bali, namely in the form of the design of the development of online learning for Multimedia Pembelajaran subject. The result of this design is the framework of development online learning for the subject of Multimedia Learning, which includes: model development (DELPHI), hardware and software, learning strategy, application architecture and application evaluation instruments. With this development, the framework is expected to be an alternative as material input the developers of online learning that involves interactive multimedia.
\end{abstract}

\section{Keywords}

Multimedia learning, online learning, development framework, interactive multimedia

\section{INTRODUCTION}

Online learning for a College in the era of now is an inevitability to be developed. It is an alternative learning supported by advances in information and communication technology (ICT), but was expected to remain mindful of the principles of interactive learning, creative and effective. Learning delivered through Web-based technologies or Internet based [1], of course with the students could reside on the place/location and different time/opportunity through computer equipment/laptop or mobile phone. According to [2] and [3], the growth in online learning is happening so fast and widespread in the last decade, particularly if viewed from a number of aspects of the reception of participants/students. They mention that, factors that contribute to such growth, for example: the reputation of institution (accreditation status), the relationships between participants, prices/fees and associated costs, decreased/absence of face-to-face class meetings/face transfer of credit policies, and an efficient registration process. Related to online learning, [4] stated that, the interactive activities on the online learning is done individually can improve learning outcomes students/student compared to traditional face-to-face classes.
Associated with it, the Government has appealed to parties in College/University to prepare everything related to infrastructure distance education based on e-learning, as stated in the Ministerial Regulation Education and culture the number 109/2013, about the Organization of distance education (online learning/distance education) in higher education. The problem is how to prepare the infrastructure? Of course it is not easy and quite a lot of things that need to be prepared/considered, ranging from the aspect of content acquisition, teaching and professional development for teachers, technology, student support, program budgeting and staffing, program evaluation [5]. Considering the aspects that must be prepared in developing online learning (a type of eLearning) is quite extensive, this research focus on supporting technology and learning strategy aspects, that aims to build a framework or design development of online learning based on interactive multimedia in STIKOM Bali for the subject of multimedia learning.

Relevant to the matter above, STIKOM Bali as a college field of information and communication technology (ICT) certainly motivated and moved to participate in preparing the online learning. In developing online learning, as a new system, surely expected not to interfere with the e-learning system which already exists. The e-learning systems that are already running, still learning content delivery strategies are asynchronous and not interactive (upload/download materials by the lecturer/student).

The development of online learning in STIKOM Bali is done gradually, through the pilot project for the Intruduction to Information Technology (PTI) and the Concept and Application of Information System (KASI) subjects on some classes (working together with the other party). This work has been started since the academic year 2017/2018. Based on those experience, for the acceleration of the development of this project, researchers/developers at stikom bali needs to review and build on the framework of the development of online learning to the next development. Furthermore, the framework will be used to develop online learning based on interactive multimedia for Multimedia Pembelajaran subject.

In establishing a framework for the development of online learning based on interactive multimedia learning, certainly need to consider at least the development of multimedia technology (multimedia authoring) and internet (learning management system or LMS) that enables harmonious online learning faster and innovative, yet still meet the elements of effectiveness and usability of interactive multimedia learning.

In order to meet the elements, in the construction/ development, course developers need to apply one of several models or methods of development of multimedia learning [6], for example: ADDIE [1], DDE [7], Delphi [8], consider to applying the principles that relate to learning [9], namely: 
learning strategies, animation, and multimedia interactivity. The result of this design is in the form of framework the development of online learning for the Multimedia Pembelajaran subject, which includes: model development (DELPHI), hardware and software (Captivate and Moodle), learning strategies, application architecture and the evaluation instrument of multimedia learning modules. The development framework is expected to be alternative ways for beginner developers online learning based on interactive multimedia learning.

\section{METHODS}

This research was conducted through the following ways: (a) the limited review of some of the literature related to learning through multimedia and online learning, for example: models development of multimedia learning, the principles of information presentation in multimedia formats, and the framework of developing online learning; (b) verify, explore and test the capability of multimedia authoring software (Adobe Captivate 10) compatible with LMS (Moodle 3.4) that aligned with the characteristics of online learning that are expected, and easy to learn; and (c) putting together the framework of online learning to further development.

\section{RESULTS AND DISCUSSIONS}

\subsection{The Results}

The Research results, based on the experience of the development of online learning pilot project in STIKOM Bali, with the minimum conditions that must be prepared as a framework for the development of online learning-based interactive multimedia, includes 5 items: (1) hardware computer which consists of a PC/Laptop with 8 GB RAM, 2.5 GB of Processor, with 64 bit system type; (2) multimedia authoring software Adobe Captivate 10, and LMS Moodle 3.4; (3) the DELPHI model for the development of multimedia learning [9]; (4) learning strategies; and (5) evaluation instruments of the learning modules. Furthermore, the frame of development can be applied to any subject. The examples of a screen capture from Multimedia Pembelajaran learning subject as figures 1a (from a Laptop/PC display), and $1 b$ (from a mobile phone display). It appears that each sentences in each display adapts to the available spot capacity, as the impact of responsive capabilities of Adobe Captivate.

\subsection{Discussions}

\subsubsection{Development Framework}

The five elements of the framework for development of multimedia-based interactive online learning can be presented as application architecture (figure 2). In figure 2, it appears that to build a interactive multimedia learning modules needed a PC/Laptop with a capacity as above (item 1) which has been installed Adobe Captivate 10 (Window or Mac), content in the form of digital material that will be taught (divided into several topics and subtopics), and the model of development of DELPHI. Using Adobe Captivate 10, these materials are processed into modules of interactive multimedia learning. There are two modes, when building a interactive multimedia learning modules, namely a responsive mode (some form of desktop, iPad, mobile phone or gadget display) and desktop mode (one type of display on the PC/Laptop). Nevertheless, the construction of the interactive multimedia learning modules is done via the desktop mode can also be converted to a responsive mode, of course, need an adjustment against the display it generates (iPad, mobile/gadget), so by all designs can be obtained a variety of display when in publish. However, in Adobe captivate 10, the condition can be resolved automatically by the instruction menu 'Fluid Box'. Captivate provides an alternate results when published, i.e. a file with the extension exe, swf, and html. For the purposes of enabling the file can be read by Moodle, can use the html type files with settings on the Sharable Content Object Reference Model (SCORM) when will publish in.

\subsubsection{Interactive Multimedia Learning}

In order a interactive multimedia learning module produced effective, must meet the process as steps on the development Model of Multimedia Learning (DELPHI). These steps include:

3.2.2.1 Define the instructional goal, learning objective, and the needs of audiences or students

At this stage it is necessary to define what students should learn and understand. Then set the learning objectives explain what students will be able to do after learning done with measurable results. In addition, to make the learning objectives can be achieved, then the need to also understand the needs of audiences or students.

\subsubsection{Verify or investigate the results of existing} module or development

The necessity of verifying or investigating the existence of previous applications ever owned/created to be made into consideration the next development.

\subsubsection{Spesify the output format, budget, and timeline}

After that to think about how to format the output (in the form of CD/DVD, or a file, a Web application/mobile). Based on the output format that will be produced, to be specified budgets and timelines.

\subsubsection{Determine the content, learning activities, and assessment strategies}

Based on those results (3.2.2.1, 3.2.2.2, and 3.2.2.3), determined the content/material to be delivered, the activities and strategy of asesments. Based on the learning objective can be determined general/special purpose of learning and content/material to be learned. After that, the content analyzed, styled/sorted, and presented. The problem lies in how the content is presented in a multimedia format? To that purpose, the principles of presentation of information in multimedia formats need to be considered [9], namely:

(a) the multimedia principle: students will learn better from animation and narration (audio) than with just the narrative only,

(b) the contiguity principle: students will learn better if the words (text) is served near the portion of the animation (image) is relevant. Likewise, when associated with narration and animation are presented at the same time rather than consecutive,

(c) The coherence principle: students will learn better from animation and narration when words (text), sound, and images that are not relevant are removed rather than incorporated

(d) The modality principle: students will learn better from animation and narration than animation and text on the screen (visual),

(e) The redundancy principle: students will learn better from animation and narration than animation, narration, and text on the screen,

(f) The segmentation and pretraning principle:: students will learn better when available facilities to manage the 
processing of esensiil in order to avoid excess load (overloading) the cognitive system (e.g. through the stop, previous and next button). Likewise, when given the material orientation session quickly related material/content delivered before the presentation begins. The condition required to enable the initial knowledge/previous (prior knowledge),

(g) The personalization principle: students will learn better from animation and narration with conversation style than formal style.

Once the media presentation of the content in the form of interactive multimedia learning, further defined how the lesson activities (individual/group/problem based learning, etc.) and so does the assessment. Assessment (middle test or final examination) should correspond to the learning objectives. In the context of online learning in STIKOM Bali, the lesson/learning activities (for one semester) are individual/independent learning with learning strategies are as follows:

(1) Accordingly the scope of the content, the content is divided into multiple topics

(2) Select and set topics with content if delivered does not exceed 12 meetings

(3) Sort by material/topics in a logical sequence

(4) Create digital content/interactive multimedia learning from each topic

(5) Create summary and questions/exercises for each topic

(6) Depending on the type of content (conceptual, procedural/ process, or principle), during the learning process, there is a minimum of 4 meetings are offline or in class (face-toface). Twice during the period of UTS (middle test) in the beginning and the end, twice during the period of UAS (final examination) in the beginning and the end. So in one semester, the number of meetings can be 16 times (exclude UTS and UAS). Face-to-face meetings can be used for explanation, discussion or content review.

(7) Offline meetings (face-to-face) can be replaced by synchronous online learning (virtual class)

(8) In the period before the UTS/UAS, students can pick up/learn material consecutively, with no prerequisites must pass on a topic before. The value can be revised on the other occasion.

(9) Final examination is conducted simultaneously in the classroom

3.2.2.5 Develop evaluation strategies, criteria, and instruments to assess the project effectiveness

In the process of building a multimedia interactive learning modules, so that the results or products obtained effective, need to set evaluation strategy, criteria, and what instruments will be used, in order to state that the project is effective. Associated with it, there are 10 critical indicators of quality (score 1-5 points scale) as a reliable tool to assess Multimedia Learning Material (MLM) [10]: (1) learning objectives are clearly stated, (2) language is appropriate to the target students or audiences, (3) the delivered content is accurate and, (4) the content is aligned with the learning objectives, (5) the instructions are available with clear instructions, and how to use it, (6) the content readable and understandable , (7) multimedia learning module (MLM) is interactive, (8) the use of the media is appropriate, (9) the interface is user-friendly
(10) the MLM is sensitive to gender and socio-cultural factors. A MLM is considered having quality if the critical indicators are rated above average.

\subsubsection{Develop the flowchart, site map, and/or} storyboard

Flow diagram (flowchart), menu structure/web (sitemap), and storyboard are visual methods that represent clear pictures of learning content. Flowchart is used to describe visually sorted steps and decisions required to implement the process. Each step in the order noted in the form of a diagram. Sitemap is used to describe visually the menu structure of application or Web page. Storyboards is used to represent detailed multimedia elements contained on each screen/slide. Storyboarding helps designers in planning audio/sound, text, graphics, video, and animation and user interaction on each screen.

\subsubsection{Develop a prototype}

A prototype is a working model or design project. The prototype is importance and needed before too much time and money invested into the development process. During this phase, developers test to consider the effectiveness of multimedia learning modul in achieving the learning objectives and the usability of application.

\subsubsection{Perform a formative evaluation}

A formative evaluation is useful for collecting data and information as the feedback of students or audiences when the project is built. The results of the formative evaluation can give an idea or consideration of how to improve the discrepancies of learning material or procedures that are already designed and is being developed [11]. The formative evaluation process should include feedback from several types of stakeholders (including student) to the content experts and clients [12]. The following instrument (table 1), related to the quality of multimedia learning module with score $1-5$ points of Likert Scale, has been tested in the reliability and can be used to conduct a formative evaluation [10]. There are three phases in obtaining data/information related to the assessment of quality [13], namely:

(1) phase of the clinical (one-on-one participant),

(2) the group phase (small groups of participants), and

(3) case studies (up to 30 participants).

\subsubsection{Complete the design}

If the performance of the prototype has been completed and in accordance with the purpose of building a multimedia learning modules, then the final form of the product/this module as a learning application must be completed and fully functional. This phase includes the completion of video, audio, graphics, photos, animation, assessment, activity, and other learning materials.

\subsubsection{Perform a summative evaluation of product and process}

A summative or final assessment is divided into two phases: a review by experts and field studies [13]. It is recommended that third parties conducting a summative evaluation [12]. In the second phase, an experimental fields to get feedback directly from the students targeted. 


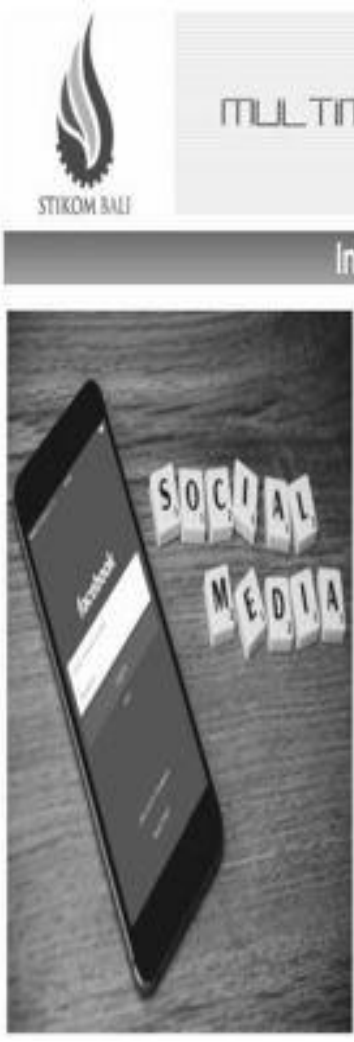

Inovasi dalam Pembelajaran

Figure 1a: Screen capture of Laptop/PC

$$
\text { Apa itu multimadia }
$$
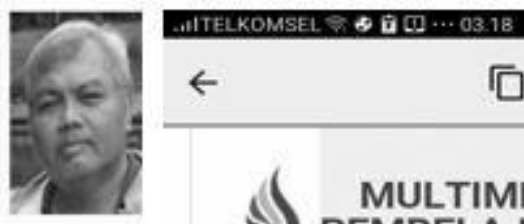

$$
\leftarrow
$$
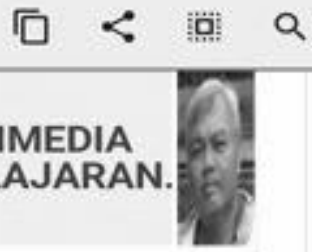

Inovasi dalam Pembelajaran

Pertimbangan penggunaan multimedia dalam pendidikan

$$
\text { Manfaat multimedia dalan penditikan }
$$

Keterbatasan multimedia dalam pendidikan

Mengenbangkan multimedia penbelajaran yang eféktif

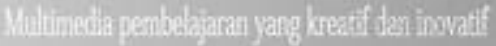

$\leftarrow$

Figure 1b: Screen capture of mobile phone

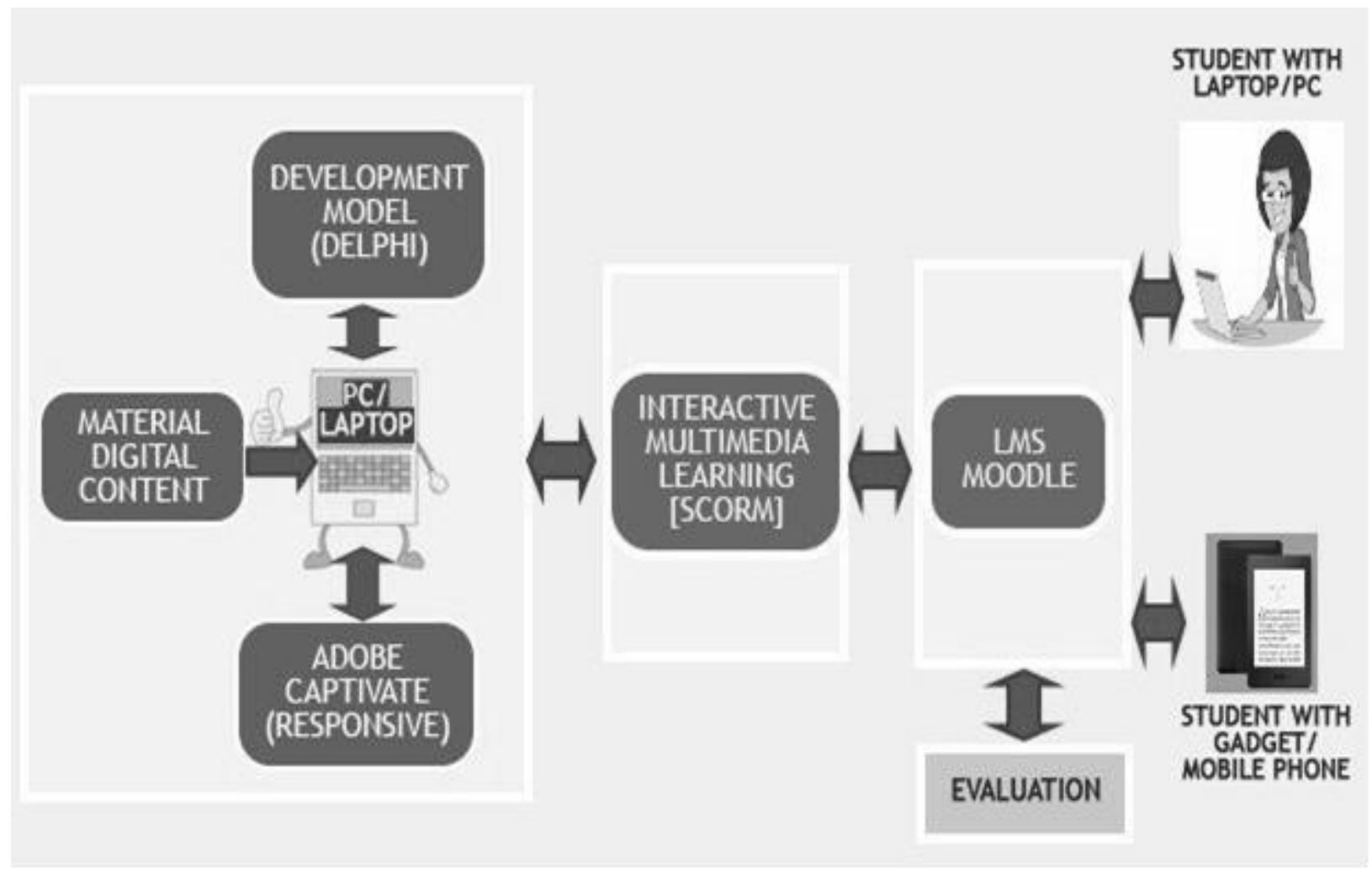

Figure 2: Application Architecture of Online Learning Based on Interactive Multimedia 
Table 1: The Instrument of Assessment for Quality of Multimedia Learning Material (MLM)

\begin{tabular}{|c|c|c|c|c|c|c|}
\hline \multirow{2}{*}{ No } & \multirow{2}{*}{ Quality Indicators } & \multicolumn{5}{|c|}{ Score of Likert Scale * } \\
\hline & & 1= Poor & 2=Average & 3= Good & 4 = Very Good & $5=$ Excellent \\
\hline 1 & $\begin{array}{l}\text { Learning Objectives (LO) } \\
\text { are clearly stated }\end{array}$ & & & & & \\
\hline 2 & $\begin{array}{l}\text { Language is appropriate } \\
\text { to target the audiences }\end{array}$ & & & & & \\
\hline 3 & $\begin{array}{l}\text { Content is accurate and } \\
\text { factual }\end{array}$ & & & & & \\
\hline 4 & Content meets objectives & & & & & \\
\hline 5 & $\begin{array}{l}\text { Clear instructions are } \\
\text { available on how to use } \\
\text { the content }\end{array}$ & & & & & \\
\hline 6 & $\begin{array}{l}\text { Content is easy to } \\
\text { understand }\end{array}$ & & & & & \\
\hline 7 & MLM is interactive & & & & & \\
\hline 8 & $\begin{array}{l}\text { The use of media is } \\
\text { appropriate }\end{array}$ & & & & & \\
\hline 9 & $\begin{array}{l}\text { The interface is user } \\
\text { friendly }\end{array}$ & & & & & \\
\hline 10 & $\begin{array}{l}\text { MLM sensitive to gender } \\
\text { and socio-cultural factors }\end{array}$ & & & & & \\
\hline
\end{tabular}

*Note: a. Give check mark $(\sqrt{ })$ in the column for the field that is most appropriate b. If the average of all the critical indicators value is greater than 3, then MLM has a good quality

\section{CONCLUSION}

The Framework of Development Online Learning based on interactive multimedia, with minimum requirements, has been created in STIKOM Bali for the Multimedia Pembelajaran subject. Nevertheless it can be implemented on any subject. The framework involves: : (1) hardware computer which consists of a PC/Laptop with minimum 8 GB RAM, 2.5 GB of Processor, with 64 bit system type; (2) Adobe Captivate 10 as a multimedia authoring tool, to create the interactive multimedia learning; (3) Moodle 3.4 as a LMS, to deliver the interactive multimedia learning and perform the tracking students learning activities and results; (4) DELPHI as a Model Development of Multimedia Learning, to make the interactive multimedia learning product is effective and usable; and (5) learning strategies, to arrange the content, the learning schedule and activities; and (5) evaluation instruments of the learning modules, to evaluate whether the learning module is usable. Development schemes can follow the Application Architecture of Online Learning Based on interactive multimedia learning (figure 2).

\section{ACKNOWLEDGMENTS}

Thanks to the management of STIKOM Bali for the support and funds on this research.

\section{REFERENCES}

[1] Ghirardini, B. 2011. E-Learning Methodologies: A Guide for designing and developing e-learning course. RomeItaly: FAO.
[2] Allen, I. E. \& Seaman, J. 2013. Grade change: Tracking online education in the United States. Babson Survey Research Group and Quahog Research Group, LLC.

[3] Aslanian, C. B. \& Clinefelter, D. L. 2013. Online college students 2013: Comprehensive data on demands and preferences. Louisville, KY: The Learning House, Inc.

[4] MacKenzie, L. \& Ballard, K. 2015. Can Using Individual Online Interactive Activities Enhance Exam Results? MERLOT Journal of Online Learning and Teaching. 11(2), 262-266.

[5] CCSESA. 2011. California eLearning Framework. California County Superintendents Educational Services Association. California.

[6] Puzziferro, M. 2015. A Model for Developing HighQuality Online Courses: Integrating a Systems Approach with Learning Theory. Journal of Asynchronous Learning Network. Vol. 12; Issue 3-4.

[7] Ivers, K. S., \& Barron, A. E. 2010. Multimedia projects in education: designing, producing, and assessing. United States of America: Library of Congress Cataloging-in-Publication Data.

[8] Frey, B.A. \& Sutton, J.M. 2010. A Model for Developing Multimedia Learning Projects. MERLOT Journal of Online Learning and Teaching; 6,2; 491-507.

[9] Rusli, M., Hermawan, D. \& Supuwiningsih, N.N. 2017. Multimedia Pembelajaran yang interaktif: Prinsip Dasar dan Model Pengembangan. ANDI. Yogyakarta 
International Journal of Computer Applications (0975 - 8887)

Volume 181 - No. 27, November 2018

[10] Nasir, S.J.A., Asirvatham, D., \& Khalid, H.H.M. 2012. Quality Framework for Assessment of Multimedia Learning Materials Version 1.0. Procedia-Social and Behavioral Sciences 67, 571-579.

[11] Gagne, R., Wager, W., Golas, K. \& Keller, J. 2005. Principles of Instructional Design. Wadsworth/ Thompson Learning.
[12] Cennamo, K. \& Kalk, D. 2005. Real Word Instructional Design. Belmont, CA: Wadsworth/Thompson Learning.

[13] Dick, W., Carey, L. and Carey, J.O. 2001. The Systematic Design of Instruction. (5th Edition). AddisonWesley Educational Publishers, Inc. 